Canadian University Music Review

Revue de musique des universités canadiennes

\title{
Walter Frisch, ed. Brahms and His World, Princeton: Princeton University Press, 1990. 223 pp. ISBN 0-691-09139-0 (cloth), ISBN 0-691-02713-7 (paper)
}

\section{James Deaville}

Volume 12, numéro 1, 1992

URI : https://id.erudit.org/iderudit/1014221ar

DOI : https://doi.org/10.7202/1014221ar

Aller au sommaire du numéro

Éditeur(s)

Canadian University Music Society / Société de musique des universités canadiennes

ISSN

0710-0353 (imprimé)

2291-2436 (numérique)

Découvrir la revue

Citer ce compte rendu

Deaville, J. (1992). Compte rendu de [Walter Frisch, ed. Brahms and His World, Princeton: Princeton University Press, 1990. 223 pp. ISBN 0-691-09139-0 (cloth), ISBN 0-691-02713-7 (paper)]. Canadian University Music Review / Revue de musique des universités canadiennes, 12(1), 149-154.

https://doi.org/10.7202/1014221ar

All Rights Reserved (c Canadian University Music Society / Société de musique des universités canadiennes, 1991
Ce document est protégé par la loi sur le droit d'auteur. L’utilisation des services d'Érudit (y compris la reproduction) est assujettie à sa politique d'utilisation que vous pouvez consulter en ligne.

https://apropos.erudit.org/fr/usagers/politique-dutilisation/ 
was not a first language. Descriptive accounts and, even worse, abstract ideas in several papers (especially those by Czechanowska, Reinhard, and Yeh) are unclear, seemingly muddied by the process of translation. While some musical transcriptions, such as those of Kaeppler or Petrovic, appear to be exemplary representations, others omit song texts (e.g., Brandes) or labels for formal sections to which reference is made in the text of the article (p. 127 or p. 93). Other inconsistencies (e.g., the different spellings of the Turkish delbek) are less daunting for the reader.

More substantial "problems" must be identified if we compare this collection of essays to the broader interdisciplinary base of feminist research. While the authors are, for the most part, cognizant of their own influence on the shape of their research, few (Kimberlin being the most noteworthy exception) articulate the intellectual and ethical challenges accruing to the representation of their own participation and that of other individuals. (This is hardly an issue exclusive to feminist study; it has, of course, been widely discussed in ethnomusicology and most social sciences.) Perhaps more serious is the apparent acceptance that meaning is unified and intra-culturally homogeneous. The post-modern attention to "readings," or feminist explorations of the nature of subjectivity would serve as theoretical underpinnings for a reinterpretation of the fascinating descriptive data presented here. So, too, would the performance theory of Victor Turner, Richard Schechner, and others. In general, with some exceptions such as the study of Tolbert, the volume is largely descriptive rather than interpretive. The useful theoretical tools developed in recent decades for studying the socially grounded meaning of expressive culture have not been much utilized.

In reality, however, this criticism is not directed toward individual scholars but more toward the reticence of the music profession to engage in the intellectual refinement of critical theories which could serve as powerful interpretive tools in music (as they have in other disciplines). The relative newness of gender studies in music, combined with the extensive amount of interdisciplinary retraining which scholars must individually undertake to conduct such studies with theoretical tools of some sophistication, are formidable but, in my view, exciting challenges.

WALTER FRISCH, ed. Brahms and His World. Princeton: Princeton University Press, 1990. 223pp. ISBN 0-691-09139-0 (cloth), ISBN 0-691-02713-7 (paper).

The malaise, which might be termed schizophrenia, that currently characterizes both musicology in general and 19th-century studies in particular, is a result of 
the challenge issued by Joseph Kerman, Lawrence Kramer, Leo Treitler, and other anti-positivists during the last two decades. Their compelling argument against Western positivistic, decontextualized approaches to music called "analysis," and by traditional association, "musicology," in favour of "criticism," has to a certain extent divided the musicological world into two camps. On the one hand, some members of the scholarly community continue to produce source and analytical studies rooted in the aforementioned tradition. On the other hand, individual attempts have been made to apply advances in such diverse fields as feminism, hermeneutics, phenomenology, semiotics, and deconstruction to gain new perspectives on music in a much broader context. This great variety of available paradigms and the failure of any yet to achieve ascendancy has led to a certain fragmentation, with the common thread being the rejection of the positivistic approach to music. As Treitler has observed, this reaction "reflects internal needs in musical studies, a desire for versatility and freedom from the rigidities of inherited dogma." [Treitler 1989:2]

For 19th-century studies, the crisis of approach is particularly keenly felt, since research devoted to each composer is at such different stages. For example, Liszt scholarship is still in its infancy - at the moment, teams of researchers are compiling a definitive thematic catalogue and are publishing a critical edition of his writings, whereas a reliable edition of Liszt's letters appears to be a matter for the distant future. (The anti-positivists might argue against the value of such undertakings, but they represent the necessary foundations for any further study, whatever the manner of inquiry.) Furthermore, Liszt research has yet to experience the wealth of insight afforded by the application of the aforementioned approaches to the oeuvres of such composers as Mozart, Verdi, or Wagner.

In contrast, Brahms research is at a more "advanced" state (perhaps due to his traditional status as a more "respectable" composer), as reflected in the existence of a recent thematic catalogue [McCorkle 1984], a reasonably reliable edition of the important letters (16 volumes, published between 1910 and 1922 by the Deutsche Brahms-Gesellschaft in Berlin) and a number of rather sophisticated monographs about the composer's music (for example, Frisch 1984). However, the anti-positivists have yet to make their influence felt also within the ranks of the Brahmsians, perhaps in this case because of the positivistic mystique that has surrounded the composer's creative oeuvre. And yet Brahms himself was a product of a certain cultural ethos. Thus it was with high expectations that the book entitled Brahms and His World was greeted by those who desired better to understand the shaping forces surrounding the composer.

The book itself gives reason for these expectations since its purpose as stated in the preface is to contextualize Brahms, to place him in the context of his own 
time; and indeed, the volume adopts a format and section divisions that affirm those goals. New wine requires new wine skins, and thus the editor Walter Frisch has eschewed any semblance of the old life and works organization, adopting instead a three-section form that comprises "Essays," "Reception and Analysis," and "Memoirs." The six "Essays" explore Brahms's relationship to his world from personal, cultural-aesthetic, compositional and piano-technical sides (to quote Frisch). In "Reception and Analysis," four contemporary or almostcontemporary reviewer-analysts examine differing genres of works by Brahms and Joseph Joachim. The three "Memoirs" shed light on the composer from the viewpoints of a pupil, an important friend and critic, and two noted composers of a later generation. In all, the broadly conceived volume contains thirteen contributions by fourteen authors, ranging from contemporaries Adolph Schubring, Hermann Kretzschmar, and Eduard Hanslick through Alexander von Zemlinsky and Karl Weigl to Frisch, George Bozarth, and Nancy Reich (among other modern contributors). It should be noted that the book had its origins in a 1990 music festival entitled "Rediscovering Brahms," which took place at Bard College - the volume was intended to serve as a "companion" to the musical performances at the festival.

How successful is the book in achieving its goal of contextualizing Brahms? To find the answer, which is by no means straightforward or unequivocal, involves examining the book first from the viewpoint of its authors' specific treatment of the various topics, and then from the broader perspective of whether those contents really represent the "world of Brahms." The editor's tacit desire to encompass Brahms's world in the book has resulted in a great diversity of contents, which - while succeeding at the level of the volume as a whole - has a disturbing effect within the section of essays. The specific sectional division, scrutinizing Brahms as it does through three radically different "hermeneutic windows," represents a brilliant post-modern approach to composer studies that certainly merits emulation. The individual essays, however, have a jarring effect through their divergence: while three articles provide complete overviews of certain general topical areas (Peter Ostwald on Brahms's personality, Nancy Reich on his relationship with Clara Schumann, and George Bozarth and Stephen Brady on Brahms's pianos), two contributions deal with quite specialized issues (Leon Botstein on the listening experience in Brahms's Vienna and David Brodbeck on possible models for the Third Symphony). The sixth essay, by Walter Frisch on Brahmsian influence at the turn of the century, successfully combines the two approaches by surveying in detail a limited body of works. All of the essays may attempt to place Brahms in the context of his age, but ironically, the less speculative overviews (including Frisch's contribution) that largely rely upon traditional documentary techniques are more satisfying. An exception to 
the documentary approach is Ostwald, who intriguingly - yet convincingly applies speculative psychoanalysis. Reich weaves a sensitive, compelling narrative, which may be considered feminist in its championing of Clara Schumann and yet does not explicitly refer to feminist theory or jargon. In comparison, neither Botstein's speculative meanderings nor Brodbeck's analytical musings are particularly satisfying - above all, the specialized, conjectural conclusions they draw are not very convincing. It should be noted that this divergence is also reflected in the style of the essays, with the overviews clearly aimed at a general readership, but the specialized studies accessible only to the musicologist.

As previously mentioned, it is the mélange of essays, contemporary analyses and memoirs that constitutes the novelty and strength of Brahms and His World. The selection of analyses and memoirs is particularly fortuitous, both taken individually and in juxtaposition with the modern essays. They represent a cross-section of late 19th-century critical and analytical thought about Brahms, which illuminates not only the Brahmsrezeption of his time but also the general state of criticism during his lifetime. The Schubring analyses of 1862, which are characterized by insight, detail, and a balance between critical and laudatory comments, are all the more remarkable because they appeared in the Neue Zeitschrift, the vehicle for the oppositional New-German School. (It should be noted that after 1861, Franz Brendel, the editor of the journal, adopted a progressively more moderate stand in the dispute with the "absolutists," publishing articles more sympathetic to Brahms and his adherents.) The writings by Kretzschmar and Hanslick are occasionally remarkable in their perspicacity and - like the Schubring reviews - furnish insights into the language used by writers of the period in discussing music. The Hanslick passage reveals that even the most dogmatic autonomists drew upon expressively-charged referential images and language. For example, he observes that "we hear half-suppressed sobs from the violins and mighty storms from the piano" in the first movement of the Violin Sonata in D Minor, op. 108. Hanslick even remarks about the work that "each of the four movements tells a different story, but we nevertheless perceive each of the tales as belonging together"!

The memoirs each contextualize Brahms in a different manner. For those interested in an overview of such matters as the composer's education, friendships, compositional activities, and attitudes toward Austrian politics and society, the lengthy, complete memoir by Hanslick (with transcriptions of letters by Brahms) would be of interest. The invaluable Jenner memoir constitutes the best record of the composer's views on composition, being written by Brahms's only private student in that area. The Zemlinsky and Weigl reminiscences reflect how Brahms influenced a later generation of Viennese composers. 
We must now ask whether the topics and contents of these individual articles truly present the context in which the composer lived and worked. At the outset, it may not be superfluous to remark that no one volume can be expected to accomplish that in a comprehensive way for any composer. Thus, it is to the editor's and contributors' credit that the book treats the plethora of aforementioned topics and of individuals from the Brahms circle. Nevertheless, there is some justification for inquiring into the relative neglect of certain important aspects of Brahms's world, like the politics of Francis Joseph's Austria and like the nature of music criticism and journalism and the sociology of performing organizations in Brahms's Vienna. Also conspicuous is the absence, if not omission, of discussion of several prominent composers from Vienna in the second half of the 19th century (e.g., Bruckner and Wolf). Considering that the Bard College festival programmed works by Joachim, Clara Schumann, Zemlinsky, Johann Strauss, Eugen d'Albert, and Robert Fuchs, it is unfortunate that only three of these composers are dealt with to any extent in the book and that other important individuals from Brahms's extended circle (including the Herzogenbergs and Julius Otto Grimm) receive only passing reference. More disturbing is what appears to be a condescending attitude toward the composers surrounding Brahms, whose works - like Joachim's Hungarian Concerto for Violin-are presented as taking on significance in their relationship to Brahms's oeuvre, and not necessarily as skillful, independent creations that may have prominently figured in the musical world of which Brahms was part and in which he worked.

The quality of the translations, primarily by Susan Gillespie and Frisch, is uniformly high, and the book is also a paragon of careful editing. In light of these achievements and the previously mentioned commendable features of the volume, certain problems - the inadequacy of the index and the hasty appearance of typography (unjustified right margins, etc.) - become secondary in importance.

The temptation for the reviewer would be to recommend this volume's particular approach as a model for other composer studies. The festival organizers and Princeton University Press have already anticipated this advice, however, by producing a second book in the same format, dedicated to Mendelssohn, who was the subject for the Bard College festival in 1991. Although this time a Mendelssohn scholar has edited the book, entitled Mendelssohn and His World, it appears to be identical to Brahms and His World in purpose and very similar in contents and organization, moreover using the talents of a number of the same contributors: Botstein, Brodbeck, and Reich for essays and Gillespie for translations. While it transcends the mandate of this reviewer to present any review 
of the "series" as a whole, he nevertheless would like to encourage the festival organizers and publisher to continue the undertaking, perhaps as a titled series (with some indication of future volumes) in an expanded hardback format that could accommodate a greater diversity of contributions and contributors. As it is now, the interested reader will simply have to wait and hope that other festivals take place, with published companion volumes.

James Deaville

\section{REFERENCES}

FRISCH, WALTER.

1984: Brahms and the Principle of Developing Variation. Berkeley: University of California Press.

MCCORKLE, MARGIT.

1984: Johannes Brahms:Thematic-Bibliographical Catalog of his Works. Munich: G. Henle.

TREITLER, LEO.

1989: Music and the Historical Imagination. Cambridge: Harvard University Press.

CRAIG WRIGHT. Music and Ceremony at Notre Dame of Paris, 500-1500 (Cambridge Studies in Music). Cambridge: Cambridge University Press, 1989. xvii, 400 pp. ISBN 0-521-24492-7

Le professeur Craig Wright, dont le monde scientifique connaît les publications sur la musique dans le domaine bourguignon aux XIVe et $\mathrm{XV}^{\mathrm{e}} \mathrm{s}$., s'est attaqué au grand et vaste sujet de la liturgie et de la musique à Notre-Dame de Paris, approximativement pendant le premier millénaire de l'histoire de la cathédrale (500-1500) ou plus exactement des trois cathédrales successives, l'actuelle celle de Maurice de Sully - étant la troisième. Le présent recenseur étant un historien de la liturgie, c'est de ce point de vue qu'il considérera ici un livre qui est une contribution utile et importante à l'histoire de la liturgie à Notre-Dame dans les derniers siècles du moyen âge.

Entre une introduction (aux lieux et aux personnes) et une conclusion, cinq parties (II à VI) traitent successivement du chant et de la liturgie (II: plus exactement de la liturgie, en insistant sur le répertoire chanté); de l'orgue (III, à partir du XIV ${ }^{e} s$.); du personnel et des institutions (IV: en fait de la maîtrise d'une part, des relations avec la royauté d'autre part); du répertoire (polyphonique), des compositeurs et des modalités d'exécution (V). Cette énumération suffirait à 